\title{
Accuracy of albumin creatinine ratio in comparison with albumine excretion rate for diagnosis diabetic nephropathy in type 2 diabetes mellitus
}

\author{
Fatrinawati, Windarwati, Osman Sianipar* \\ Department of Clinical Pathology and Laboratory Medicine, Faculty of Medicine, Public \\ Health and Nursing, Universitas Gadjah Mada/Dr. Sardjito General Hospital, Yogyakarta, \\ Indonesia
}

DOI: http://dx.doi.org/10.19106/JMedScie/005003201806

\section{ABSTRACT}

Diabetic nephropathy (DN) is one of complications in diabetic patients manifested by microalbuminuria with minimal level of $30 \mathrm{mg} / 24$ hour which is measured at least 2 times in the period of 3 to 6 months. Microalbuminuria can be measured either albumin excretion rate (AER) or albumin creatinine ratio (ACR). Measurement of ACR is an alternative parameter recommended by $\mathrm{WHO}$ in 2011 to diagnose diabetic nephropathy since it is more convenient, fast and not requires special preparation. The purpose of this study was to investigate accuracy of ACR to diagnose DN in type 2 diabetes mellitus (T2DM) patients. This was a diagnostic test study involving 80 T2DM patients. In this study ACR value equal or more than $30 \mathrm{mg} / \mathrm{g}$ was independently and blindly compared with AER as the gold standard. The data were analyzed using $2 \times 2$ tables in order to calculate sensitivity, specificity, positive predictive value (PPV), and negative predictive value (NPV). Other data were analyzed using statistic descriptive. Eighty T2DM patients consisting of 38 males and 42 females participated in this study. They had suffered from T2DM on average 9.5 years, and the average of ACR value was $55.5 \mathrm{mg} / \mathrm{g}$. Total result of true positive and true negative was 77 . Three result were false negative but none of false positive result. The ACR value equal or more than $30 \mathrm{mg} / \mathrm{g}$ had sensitivity, specificity, PPV, and NPV of $95.9 \%, 100 \%, 100 \%$, and $66.7 \%$ respectively. In conclusion, the ACR value equal or more than $30 \mathrm{mg} / \mathrm{g}$ derived from morning urine sample can be used to diagnose DN in T2DM patients.

\section{ABSTRAK}

Nefropati diabetik (ND) merupakan salah satu komplikasi pada pasien diabetes yang dimanifestasikan sebagai mikroalbuminuria dengan nilai minimal $30 \mathrm{mg} / 24$ jam yang diukur setidaknya 2 kali dalam selang waktu 3 sampai 6 bulan. Mikroalbuminuria dapat diukur dengan laju eksresi albumin (albumin excretion rate/AER) atau rasio albumin terhadap kreatinin (albumin creatinine ratio/ACR). Pengukuran ACR merupakan parameter alternatif yang direkomendasikan Organisasi Kesehatan Dunia pada tahun 2011 untuk mendiagnosis ND karena lebih nyaman, cepat dan tidak memerlukan persiapan khusus. Penelitian ini bertujuan untuk menentukan ketepatan ACR dalam mendiagnosis nefropati diabetik pada pasien diabetes mellitus tipe 2 (DMT2). Dalam penelitian ini nilai ACR sama atau lebih dari $30 \mathrm{mg} / \mathrm{g}$ dibandingkan dengan baku emas AER secara bebas dan tersamar. Data dianalisis menggunakan tabel $2 \times 2$ untuk menetapkan sensitivitas, spesifisitas, nilai ramal positif, dan nilai ramal negatif. Data lain dianalisis menggunakan statistik deskriptif. Sebanyak 80 pasien DMT2 yang terdiri dari 38 laki-laki dan 42 perempuan terlibat dalam penelitian ini. Mereka rata-rata menderita penyakit ini 9,5 tahun dengan rerata nilai ACR $55,5 \mathrm{mg} / \mathrm{g}$. Total hasil positif benar dan negatif benar sebanyak 77 . Tiga hasil menunjukkan negatif palsu dan tidak ditemukan hasil positif palsu. Nilai ACR sama atau lebih dari 30 $\mathrm{mg} / \mathrm{g}$ memiliki sensitivitas, specifisitas, nilai ramal positif, dan nilai ramal negatif secara berurutan sebesar $95,9 \%, 100 \%, 100 \%$, and $66,7 \%$. Hal ini dapat disimpulkan bahwa nilai ACR sama atau lebih dari $30 \mathrm{mg} / \mathrm{g}$ yang diperoleh dari sampel urin pagi dapat digunakan untuk mendiagnosis ND pada pasien DMT2. 
Keywords: diabetic nephropathy - albumin creatinine ratio (ACR) - albumin excretion rate (AER) - sensitivity - diagnostic test

\section{INTRODUCTION}

Diabetic nephropathy (DN) is the most frequent single cause of end-stage renal disease (ESRD) in many countries. Hyperfiltration and microalbuminuria characterize the clinical stages of DN. Increased levels of albumin in the urine have been clearly established as an important determinant for renal complication of diabetes. Screening for increased albumin excretion has therefore been advocated to identify individual at risk for renal disease progression in a timely manner. However, there is still continuing uncertainty as to how urine should be collected and which urinary proteins should be specifically measured for prediction of renal events. ${ }^{1}$

Albumine creatinine ratio (ACR) has been proposed as both a screening and diagnostic test for kidney disease. Screening for microalbuminuria is essential as it allows interventions aimed at preventing diabetic nephropathy and part of the everyday treatment of diabetic patient for detecting kidney disease progression and also evaluation of treatment effect, therefore samples providing immediate and reliable results are highly desirable. Numerous recent studies have been shown that early morning urinary ACR for screening purpose is also a predictor of overt DN and is useful to identify patient at risk as it is less influenced by the factors such as hydration status, physical activity and concentration bias. ${ }^{2}$

Type 2 diabetes mellitus (T2DM) typically asymptomatic in the early stages of development and is generally identified only after 4 to 7 years after onset of the disease. ${ }^{3}$ Diabetes mellitus is often not diagnosed until complications appear, and approximately $30 \%$ of patients with diabetes may be left undiagnosed. Microvascular and macrovascular complications sometimes already developed, even in pre-diabetic stage. As many as $25 \%$ of people with a new diagnosis of diabetes already have diabetic retinopathy (DR) or microalbuminuria. ${ }^{4}$

It is estimated that one-third of patients with type 1 diabetes mellitus (T1DM) and one-sixth of patients with T2DM will develop DN. When DN has developed, the interval to ESRD varies from the first 4 years to more than 10 years. Based on more recent studies, it was similar between T1DM and T2DM. In present study using T2DM patients because its prevalence in Dr. Sardjito General Hospital was higher than that T1DM. ${ }^{5}$

Microalbuminuria is a laboratory parameter that can be used as predictors for the development of nephropathy in diabetic patients. However, it has an ostacle since it requires a 24-hour urine sample which causes a lot of discomfort for patient. Fortunely, nowadays it has been developed other tool to measure microalbuminuria by measuring either albumin excretion rate (AER), or ACR. ${ }^{2}$ The lack of information regarding the use of ACR in the determination of microalbuminuria has an impact on delay in diagnosis of DN. Therefore, efforts have been done in order to avoid the development of terminal renal failure that require multidisciplinary management in addition to its poor prognosis and cost. ${ }^{1}$

Currently, the data regarding ACR especially its sensitivity and specificity are still not sufficient, thus its implementation is still limited. In Indonesian population, especially in the Yogyakarta Special Region, ACR test for the diagnosis of DN in T2DM population is rarely used. Therefore, this study tried to measure the sensitivity and specificity of ACR with a cutoff value of 30 $\mathrm{mg} / \mathrm{g}$ compared with AER value using 24hour urine sample for diagnosis of DN.

\section{MATERIALS AND METHODS}

\section{Reagents and subjects}

Sample used in this study were 24hour urine, urine at random, EDTA blood 
sample as well as blood serum. In addition, reagensia kit to measure albumin, creatinine, $\mathrm{HbA}_{1 \mathrm{c}}$, blood glucose were also needed. This was a diagnostic test study where the ACR was independenly and blindly compared with the AER involving 80 T2DM patients with suspected DN who visited in Internal Medicine Outpatient Clinic of Dr. Sardjito General Hospital and agreed to undergo ACR and AER tests throughout 2015. The inclusion criteria were diabetic patients (a minimum of 4 years) with suspected DN and give written informed consent. Those patients who suffered from either urinary tract infections, or congestive heart failure, or liver dysfunction, or pregnancy, or incomplete or missing medical record data were excluded from this study. Protocol of this study has been approved by the Medical and Health Research Ethics Committee, Faculty of Medicine, Public Health and Nursing, Universitas Gadjah Mada, Yogyakarta.

\section{Protocol of the study}

Subjects had their urine albumin and urine creatinine levels measured using morning urine sample. The ACR values were calculated manually, dividing urinary albumin by urine creatinine levels. Gold standard in this study was AER that measured from urine albumin level with 24-hour urine. Standard microalbuminuria criteria used in this study were in accordance with $2002 \mathrm{NKF} / \mathrm{KDOQ}$ recommendation, ACR between 30-300 mg/g, while AER 30-300 $\mathrm{mg} / 24$ hour. $^{6}$

Eligible subjects filled out a questionnaire for baseline characteristics data such as age, sex, education, occupation, history of hypertension, history of heart disease, duration of diabetes and blood pressure (BP). Physical examination was conducted which also include weight, height, BP measurements.

Laboratory tests were carried out for 2 day. In day I, samples were taken for fasting blood glucose, 2 hour post prandial blood glucose, HbA1c, and spot urine. Fasting blood glucose tests, 2 hour post prandial blood glucose and HbA1c were measured from $2 \mathrm{~mL}$ of venous blood sample and the tests were condected in the same day of sampling. Subjects on the day I was also asked to collect $5 \mathrm{~mL}$ urine sample for urine albumin and creatinine measurements. Urine samples were then transferred into Eppendorf tubes using a standardized micropipette, then labeled and kept at $-20^{\circ} \mathrm{C}$, pooled them up to sufficient number of samples were acomplished. Subjects were also given written and oral instruction for 24-hour urine collection (when collection began, first urination was discarded then second and subsequent urination collected for 24 hour) into a $2.500 \mathrm{~mL}$ threaded cap bottle urine container.

On day 2, 24-hour urine samples were collected. The collected 24-hour urine samples were homogenized by flipping the bottles as much as 5 times, after which the urine volume was recorded. Most homogeneous urine samples were transferred into eppendorf tubes using a standardized micropipette, then labeled and stored at $-20^{\circ} \mathrm{C}$, pooled until urine albumin tests performed after certain number of samples were collected.

Fasting and 2 hour post prandial blood glucose level were measured according to hexokinase method using COBASS 6000 ANALYZER. The assay is based upon the reduction of $\mathrm{NAD}^{+}$through a coupled reaction with glucose-6-phosphate dehydrogenase and is determined spectrophotometrically by measuring the increase in absorbance at $340 \mathrm{~nm}$. Hemoglobin $\mathrm{A}_{1} \mathrm{c}\left(\mathrm{HbA}_{1} \mathrm{c}\right)$ was measured with ion-exchange Highperformance liquid chromatography (HPLC) method using Biorad D-10 ANALYZER. The ion-exchange high-performance liquid chromatography (HPLC) is based on chromatographic separation of $\mathrm{HbAlc}$ on a cation exchange cartridge in human whole blood. Urinary albumin was measured using a immunoturbidimetric method. The principle of immunoturbidimetric assay is albumin in the urine reacts with specific antibodies, then added polyethylene glycol will precipitate immune complexes that 
would cause turbidity. Turbidity is measured by photometric and its value is proportional to the levels of albumin in the urine. Urinary creatinine was measured using Jaffe method using COBASS 6000 ANALYZER. The principle Jaffe method is in alkaline atmosphere with picric acid will form compounds saffron. This color change will be measured by using a photometer. ${ }^{6}$

Albumin excretion rate was urinary albumin excretion within 24 hours. It was measured using immunoturbidimetric method using COBASS 6000 ANALYZER. Albumin excretion rate is the gold standard to assess microalbuminuria. In current study, DN is defined by AER value of $\geq 30 \mathrm{mg} / 24$ hour. The ACR was calculated manually by dividing the urinary albumin by urinary creatinine values, and the results were expressed in $\mathrm{mg} / \mathrm{g}$. In the current study, DN is defined by ACR value of $\geq 30 \mathrm{mg} / \mathrm{g}$. ${ }^{2}$ To assess reliability, before running any tests, analytic tests were first completed using calibration test, accuracy test and precision test. $^{6}$

\section{Data analysis}

Data characteristics was presented descriptively in mean and standard deviation (SD) if data had normal distribution or in median and minimum-maximum values if did not have normal distribution. Normality for continuous data was tested using Kolmogorov-Smirnov test. Categorical data were presented in proportion. To test differences in mean age, fasting and 2 hour post prandial blood glucose, independent t-test was used when data were normally distributed and Mann-Whitney test when data were not normally distributed. Meanwhile, to investigate differences in proportion, Chi-Square test was used. Results were considered significant if $\mathrm{p}$ values less than 0.05 with $95 \%$ confidence intervals.

Diagnostics performance were analyzed by $2 \times 2$ table and result was presented in sensitivity (Sn), specificity (Sp), accuracy, positive predictive value (PPV), negative predictive value (NPV), likelihood ratio
(LR) for test positive and negative results.

\section{RESULTS}

\section{Characteristics of subjects}

A total of 110 subjects were given a questionnaire, unfortunately 16 subjects did not return their questionnaires, thefore they were considered resigned from study. From the remained subjects (94 subjects), nine subjects did not collect 24-hour urine sample, five subjects without data of volume of 24-hour urine sample so that they were excluded from the study. Finally, 80 subjects were included in analysis. Total subject of the study were 80 subject consisted of females $42(52.5 \%)$ and males 38 (47.5\%). Based on age, 40 subjects were more than 60 years $(50 \%)$ and 40 subjects were less than 60 years $(50 \%)$. The characteristics of subjects are presented in TABLE 1 .

TABLE 1. Characteristics of subjects

\begin{tabular}{lcc}
\hline Characteristics & $\mathrm{n}$ & $\%$ \\
\hline Gender & & \\
- Male & 38 & 47.5 \\
• Female & 42 & 52.5 \\
Age & & \\
- $\leq 60$ years & 40 & 50.0 \\
- $>60$ years & 40 & 50.0
\end{tabular}

Education

- Elementary School $\quad 8 \quad 10.0$

- Junior High School 556

- Senior High School $\quad 37 \quad 46.3$

- Higher education $\quad 30 \quad 37.5$

Occupation

- Household $\quad 20 \quad 25.0$

- Professional 22.5

- Government employ- $6 \quad 7.5$ ees

$\begin{array}{lll}\text { - Private } & 2 & 2.5 \\ \text { - Entrepreneur } & 6 & 7.5\end{array}$

- Other $44 \quad 55.0$ 
Total subject of the study were 80 subject consisted 74 subject with DN and 6 subject non DN. No significantly different in body mass index (BMI), history of hypertension, heart disease, dyslipidemia, stroke, duration of DM, fasting and 2 hour post prandial lood glucose level, and $\mathrm{HbA}_{1 \mathrm{C}}$ level between subjects with DN and non DN was observed (TABLE 2).

TABLE 2. Characteristics of subject between ND and Non ND groups

\begin{tabular}{|c|c|c|c|}
\hline Characteristics & $\mathrm{ND}(\mathrm{n}=74)$ & Non ND $(n=6)$ & $\mathrm{p}$ \\
\hline BMI (mean \pm SD kg/m²) & $24.86 \pm 3.37$ & $25.24 \pm 2.81$ & 0.790 \\
\hline \multicolumn{4}{|l|}{ Hipertension $[\mathrm{n}(\%)]$} \\
\hline • Yes & $42(56.8)$ & $3(50.0)$ & \multirow[t]{2}{*}{1,000} \\
\hline • No & $32(43.2)$ & $3(50.0)$ & \\
\hline \multicolumn{4}{|l|}{ Heart disease $[\mathrm{n}(\%)]$} \\
\hline - Yes & $23(31.1)$ & $3(50.0)$ & \multirow[t]{2}{*}{0.384} \\
\hline • No & $51(68.9)$ & $3(50.0)$ & \\
\hline \multicolumn{4}{|l|}{ Dyslipidemia [n (\%)] } \\
\hline • Yes & $47(63.5)$ & $5(83.3)$ & \multirow[t]{2}{*}{0.659} \\
\hline - No & $27(36.5)$ & $1(16.7)$ & \\
\hline \multicolumn{4}{|l|}{ Stroke $[\mathrm{n}(\%)]$} \\
\hline - Yes & $7(9.5)$ & $2(33.3)$ & \multirow[t]{2}{*}{0.133} \\
\hline • No` & $67(90.5)$ & $4(66.7)$ & \\
\hline Duration of DM (mean \pm SD year) & $10.12 \pm 7.21$ & $9.33 \pm 9.05$ & 0.728 \\
\hline \multicolumn{4}{|l|}{$\mathrm{BP}($ mean $\pm \mathrm{SD} \mathrm{mmHg})$} \\
\hline - Sistolic & $129.84 \pm 16.17$ & $125.00 \pm 10.49$ & 0.521 \\
\hline - Diastolic & $79.39 \pm 9.43$ & $80.00 \pm 5.48$ & 0.854 \\
\hline Fasting glucose (mean \pm SD mg/dL) & $160.38 \pm 68.61$ & $139.83 \pm 17.95$ & 0.826 \\
\hline 2 h PP glucose (mean \pm SD mg/dL) & $227.05 \pm 91.58$ & $195.17 \pm 52.09$ & 0.517 \\
\hline Creatinine serum $($ mean \pm SD mg/dL) & $1.10 \pm \mathbf{0 . 2 3}$ & $0.87 \pm 0.15$ & 0.630 \\
\hline $\mathrm{HbA}_{1} \mathrm{c}($ mean $\pm \mathrm{SD} \%)$ & $7.97 \pm 2.21$ & $7.67 \pm 0.68$ & 0.891 \\
\hline
\end{tabular}

Note: BMI (body mass index); BP (blood pressure); $2 \mathrm{~h}$ pp (2 hours post prandial)

FIGURE 1. Scatter plot of AER value based on duration of DM 
It was found that AER values tend to be higher in patients with longer duration of
DM. Patients with longer duration of DM normally had higher AER (FIGURE 1).

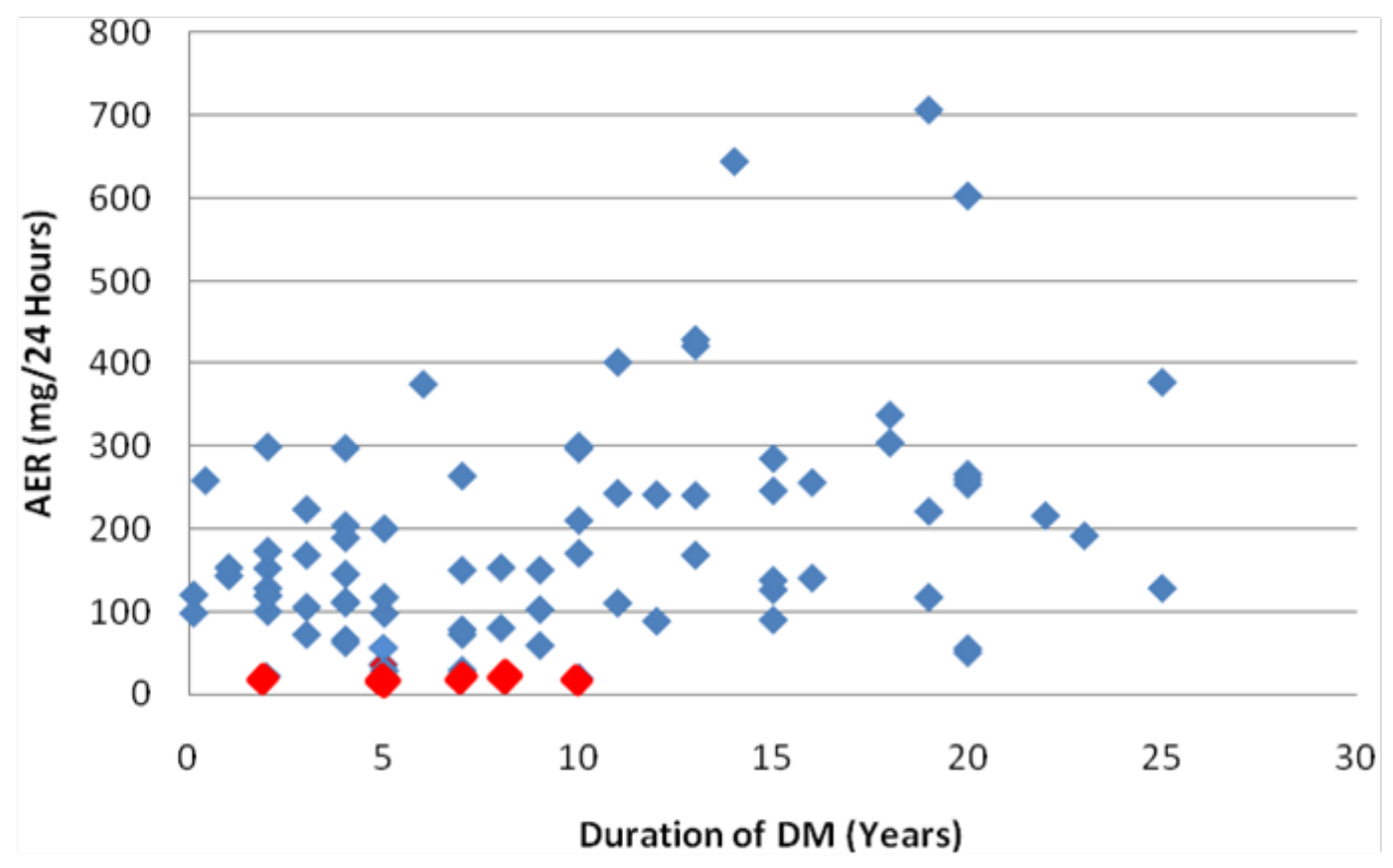

FIGURE 1. Scatter plot of AER value based on duration of DM

\section{ACR diagnostic performance}

The ACR diagnostic performance was tested using $2 \times 2$ table with AER as the gold standard for DN. It was found that both true positive and true negative rate totally 77 . It was also found 3 false negative result but none of result was false positive (TABLE 3 ). In present study, there were 3 subjects of

TABLE 3. Analysis using $2 \times 2$ table to define ACR performance to diagnose DN

\begin{tabular}{lccc}
\hline & ND & Non ND & Total \\
\hline ACR & & & \\
$\bullet \geq 30 \mathrm{mg} / \mathrm{g}$ & 71 & 0 & 71 \\
$\bullet<30 \mathrm{mg} / \mathrm{g}$ & 3 & 6 & 9 \\
Total & 74 & 6 & 80 \\
\hline
\end{tabular}

false negative diagnostic test result means when viewed from the ACR value, was not the subject with DN, but when viewed from the AER value included in subject with DN. The performance of ACR to diagnose DN were as follows sensitivity $95.9 \%$; specificity $100 \%$; positive predictive value $100 \%$; negative predictive value $66.7 \%$ (TABLE 4 ).

TABLE 4. Diagnostic performance of ACR to detect DN

\begin{tabular}{lcc}
\hline Performance of ACR & Value & $95 \%$ CI \\
\hline Sensitivity (\%) & 95.9 & $88.6-99.2$ \\
Specificity (\%) & 100 & $54-100$ \\
Accuracy (\%) & 96.3 & $92.0-100$ \\
Positive predictive value (\%) & 100 & $100-100$ \\
Negative predictive value (\%) & 66.7 & $35.9-97.5$ \\
Positive likelihood ratio (LR+) & $\sim$ & $\sim$ \\
Negative likelihood ratio (LR-) & 0.04 & $0.01-0.1$ \\
\hline
\end{tabular}


TABLE 5 as well as FIGURE 2 show the diagnostic performance of ACR ranging from 28 to $32 \mathrm{mg} / \mathrm{g}$ with $1 \mathrm{mg} / \mathrm{g}$ interval. It was shown that $\mathrm{ACR}$ value equal or more than $30 \mathrm{mg} / \mathrm{g}$ has the best performance to diagnose DN.

TABLE 5. Diagnostic performance of ACR at several cutoff values

\begin{tabular}{|c|c|c|}
\hline ACR level (mg/g) & Sensitivity (\%) & 1-Specificity (\%) \\
\hline $\begin{array}{l}\geq 32 \\
<32\end{array}$ & 97.3 & 16.7 \\
\hline $\begin{array}{l}\geq 31 \\
<31\end{array}$ & 95.9 & 0 \\
\hline $\begin{array}{l}\geq 30 \\
<30\end{array}$ & 95.9 & 0 \\
\hline $\begin{array}{l}\geq 29 \\
<29\end{array}$ & 93.2 & 0 \\
\hline $\begin{array}{l}\geq 28 \\
<28\end{array}$ & 90.5 & 0 \\
\hline
\end{tabular}

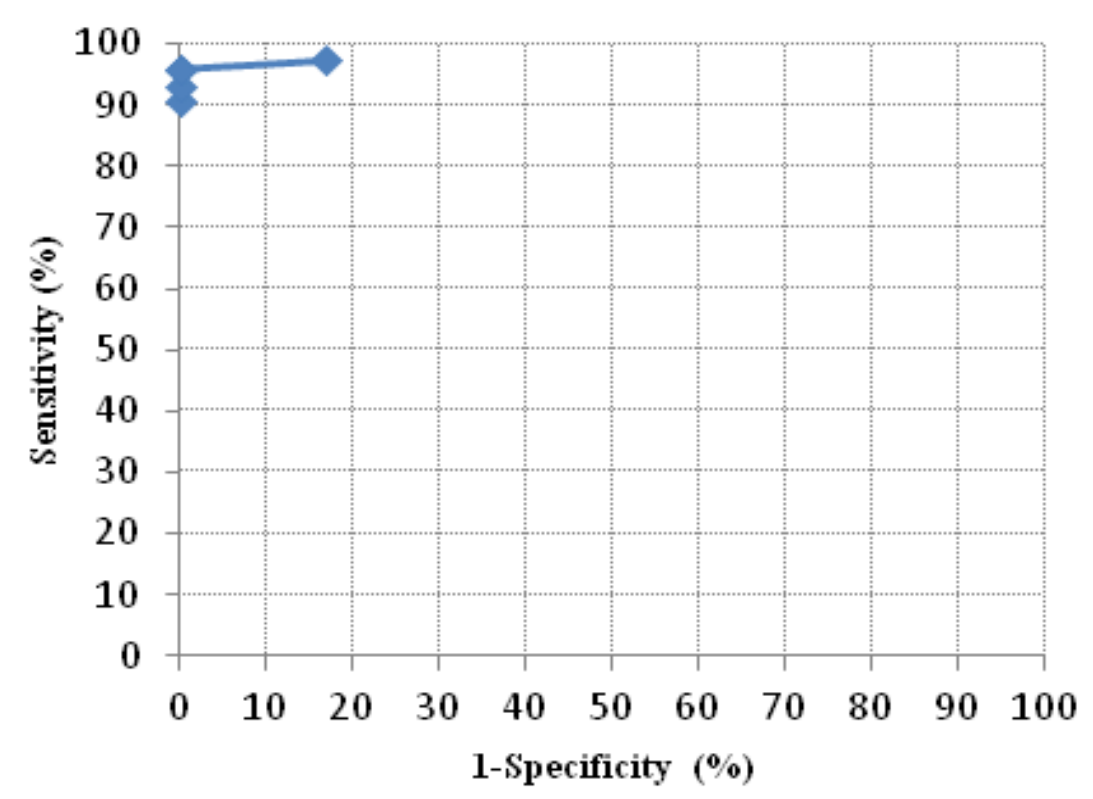

FIGURE 2. Receiver operating characteristic curve (ROC) of ACR 


\section{DISCUSSION}

The study found higher AER values in subjects with longer duration of DM. It proved that the disease has a progressive characteristic. Generally DN will be diagnosed after 4 years duration of DM and level of AER might be more than $300 \mathrm{mg} / 24$ hours. It indicated that kidney function start to decline due to lack of blood glucose control or the start of chronic hyperglycemia. After the tenth year of disease, AER values tend to return into the range of $200-300 \mathrm{mg} / 24$ hours. This is because of management with anti-diabetic and anti-hypertensive that have also function as renal protector. ${ }^{7,8}$

The study found at the level equal or more than $30 \mathrm{mg} / \mathrm{g}$, ACR has sensitivity and specificity $95.9 \%$ and $100 \%$ respectively. In present study obtained high sensitivity ACR values. High sensitivity ACR values can be used for screening DN especially for patients with chronic hyperglycemia. Previous studies reported higher specificity ACR values can be used for diagnostic purposes. Valizadeh et al. ${ }^{9}$ reported a similar study involving 201 T2DM outpatients, aged more than 40 years, and use spot urine sample. They use the same cut off value of ACR report a different result i.e. sensitivity of $100 \%$ and specificity of $93.8 \%$. They also found that ACR value was correlated with AER $(r=0.89 ; p<0.0001)$. Another similar study conducted by Jafar et al. ${ }^{10}$ involved 577 subjects, and used spot urine sample. They reported that ACR value with cut off value $30 \mathrm{mg} / \mathrm{g}$ has sensitivity and specificity $86 \%$ and $90 \%$, respectively. Another study conducted by Sampaio et al. ${ }^{11}$ involved T1 and T2DM patient with majority female, and mean of age was 31 years old. Based on cut off value of ACR $27.3 \mathrm{mg} / \mathrm{g}$ they reported that ACR has sensitivity and specificity $100 \%$ and $73 \%$, respectively. Yamamoto et al. ${ }^{12}$ conducted a study on 228 T2DM outpatients with female majority with mean of age of 60 years. Twenty four urine samples were tested for albumin, while early morning urine samples were tested for albumin and creatinine. They found that the use of ACR with cutoff value of $28.7 \mathrm{mg} / \mathrm{g}$, it has sensitivity and specificity $88 \%$ and $88 \%$, respectively.

Chae et al..$^{13}$ conducted a study with the aim to investigate the correlation between ACR and AER. Subjects consisted of 113 children and adults with T1- and T2DM patients, with mean age of 15 years and predominantly male subjects. They found that ACR value has a good correlation with AER value.

Wu et al. ${ }^{14}$ conducted a study which involved 200 T2DM patients with mean age of 40 years to assess the accuracy of ACR compared with the gold standard AER. They reported that ACR with cut off value of 30 $\mathrm{mg} / \mathrm{g}$ has sensitivity and specificity $87 \%$ and $88 \%$ respectively. Both sensitivity and specificity reported was lower than that in the our study, because the urine sample used were not in accordance with $\mathrm{NKF} / \mathrm{KDOQ}$ 2002 recommendations.

Another study was conducted to investigate the accuracy of total protein creatinine ratio in urine to diagnosis DN among T2DM patients. This ratio was independently and blindly compared with AER as the reference standard. The result showed that this ratio had a sensitivity, specificity, PPV, and NPV of $97.4 \%, 100 \%$, $100 \%$, and $81.8 \%$ respectively. ${ }^{15}$

\section{CONCLUSION}

Albumin creatinine ratio with cutoff value of $30 \mathrm{mg} / \mathrm{g}$ has sensitivity, specificity, PPV, NPV, LR-, and LR+ of 95.9\%, 100\%, $100 \%, 66.7 \%, 0.04$, and infinite respectively for the diagnosis of DN. The ACR value of $30 \mathrm{mg} / \mathrm{g}$ with a morning urine sample can be used to diagnose DN in T2DM population.

\section{ACKNOWLEDGEMENTS}

We would like to thank the Director of Dr. Sardjito General Hospital who has given permission to conduct this study. 
Our gratitude also go to the Head of the Department of Clinical Pathology and Laboratory Medicine, Faculty of Medicine Public Health and Nursing as well as all of senior staf who have given valuable input in this study. Many thanks to the Head of Clinical Laboratory of Dr. Sardjito General Hospital and staffs who help to conduct the study. The author also expressed gratitude to the patients who have been willing to participate in this study and to all those who have given support to this study. This research does not received grant from any funding agency in the public, commercial, or not-for-profit sectors.

\section{REFERENCES}

1. PERKENI. Konsensus Pengendalian dan pencegahan diabetes militus Tipe 2 di Indonesia 2015. 2015. http:/dx.doi.org/10.1017/CBO9781107415324.004

2. American Diabetes Association. Diagnosis and classification of diabetes mellitus. Diabetes Care. 2010; 33(Supplement 1):S62-S69. http://dx.doi.org/10.2337/dc10-S062

3. Asdie AH. Patogenesis dan terapi diabetes melitus tipe 2. Yogyakarta: Penerbit Medika, Fakultas Kedokteran Universitas Gadjah Mada, 2000.

4. Saudek CD, Herman WH, Sacks DB, Bergenstal RM, Edelman D, Davidson MB. A new look at screening and diagnosing diabetes mellitus. J Clin Endocrinol Metab 2008; 93(7):2447-53. http://dx.doi.org/10.1210/jc.2007-2174

5. Christensen DL, Witte DR, Kaduka L, Jorgensen ME, Borch-Johnsen K, Mohan V, et al. Moving to an A1C-based diagnosis of diabetes has a different impact on prevalence in different ethnic groups. Diabetes Care 2010; 33(3):580-2. http://dx.doi.org/10.2337/dc09-1843

6. Perkumpulan Endokrinologi Indonesia. Konsensus pengelolaan dan pencegahan diabetes melitus tipe 2 di Indonesia. Jakarta: Pengurus Besar PERKENI, 2011.

7. Fried LF, Shlipak MG, Bleyer AJ,
Gottdiener JS, Kronmal LA, et al. Renal insufficiency as a predictor of cardiovascular outcomes and mortality in elderly individuals. J Am Coll Cardiol 2003; 41: 1364-72. http://x.doi.org/10.1016/S0735-1097(03)00163-3

8. Thomas S \& Karalliedde J. Diabetic nephropathy. Medicine (Baltimore) 2015; 43(1):20-5. http://dx.doi.org/10.1016/j.mpmed.2014.10.007

9. Valizadeh R, Yoon PW, Liu T, Khoury MJ. Determining the value of albumin to creatinine ratio in a single morning sample, compared to 24 hour urin albumin excretion rate test for determining microalbuminuria. Iran J Diabetes 2009; 9: 27-36.

10. Jafar TH, Chaturvedi N, Hatcher J, Levey AS. Use of albumin creatinine ratio and urine albumin concentration as a screening test for albuminuria in an Indo-Asian population. Nephrol Dial Transplant Off Publ Eur Dial Transpl Assoc - Eur Ren Assoc 2007; 22(8): 2194-200. http://dx.doi.org/10.1093/ndt/gfm114

11. Sampaio E \& Delfino VDA. Assessing albuminuria in spot morning samples from diabetic patients. Arq Bras Endocrinol Metabol 2008; 52(9): 1482-8. http:/dx.doi.org/10.1590/S000427302008000900012

12. Yamamoto K, Komatsu Y, Yamamoto H, Izumo $\mathrm{H}$, Sanoyama $\mathrm{K}$, Monden $\mathrm{M}$, et al. Establishment of a method to detect microalbuminuria by measuring the total urinary protein-to-creatinine ratio in diabetic patients. Tohoku J Exp Med 2011; 225(3):195-202. http://dx.doi.org/10.1620/tjem.225.195

13. Chae HW, Shin JI, Kwon AR, Kim HS, $\mathrm{Kim}$ DH. Spot urine albumin to creatinine ratio and serum cystatin $\mathrm{C}$ are effective for detection of diabetic nephropathy in childhood diabetic patients. J Korean Med Sci 2012; 27(7):784.

http://dx.doi.org/10.3346/jkms.2012.27.7.784

14. Wu HY, Peng YS, Chiang CK, Huang JW, Hung KY, Wu KD, et al. Diagnostic performance of random urine samples using albumin concentration vs ratio of albumin to creatinine for 
microalbuminuria screening in patients with diabetes mellitus: a systematic review and meta-analysis. JAMA Intern Med 2014;174(7):1108-15.

http:/dx.doi.org/10.1001/jamaintemmed.2014.1363
15. Fatrinawati, Windarwati, Sianipar O. Sensitivity of total protein creatinine ratio in urine for diagnosis diabetic nephropathy. J Med Sci 2017; 49: 64-71. http://dx.doi.org/10.19106/JMedSci004902201703 